\title{
SEGMENTASI PASAR KONSUMEN PONDOK PATIN HM. YUNUS PEKANBARU
}

\author{
Dony Martias \\ Fakultas Ekonomi dan Sosial UIN Sultan Syarif Kasim Riau - Pekanbaru \\ E-mail: dony.martias@uin-suska.ac.id
}

\begin{abstract}
Abstrak
Perkembangan dalam dunia bisnis saat ini semakin maju dan berkembang termasuk bisnis pengolahan bahan pangan siap saji. Bisnis pengolahan bahan pangan siap saji seperti rumah makan, restoran, cafe merupakan salah satu bisnis yang menjanjikan saat ini. Karena rumah makan, restoran dan cafe menyediakan kebutuhan pokok yang dikonsumsi oleh masyarakat. Penelitian ini bertujuan untuk mengidentifikasi segmentasi pasar konsumen rumah makan Pondok Patin HM. Yunus Pekanbaru. Alat analisis yang digunakan adalah analisis faktor untuk menyederhanakan variabel dari segi segmentasi demografis, perilaku dari dara responden dan segmentasi psikografis yang berjumlah 22 item pernyataan. Segmentasi pasar dalam penelitian ini dilakukan berdasarkan variabel gaya hidup dengan menggunakan analisis klaster untuk mengelompokkan individu atau objek tersebut kedalam kelompok-kelompok yang mempunyai ciri dan respon yang sama. Dan dari hasil analisis faktor terhadap variabel gaya hidup terdapat 6 faktor yaitu aktif berorganisasi, optimis, senang kehidupan modern, pemerhati masalah sosial dan politik, mengedepankan status sosial dan memperhatikan penampilan. Sedangkan analisis klaster yang dilakukan terhadap gaya hidup dari variabel demografis dan perilaku menghasilkan dua segmen yaitu segmen aktif dan segmen pasif. Dengan adanya segmen yang telah diketahui, penulis memberikan saran agar rumah makan Pondok Patin HM. Yunus Pekanbaru melakukan pengembangan produk dalam pangsa pasar dengan jumlah pesaingnya sedikit yang telah disesuaikan dengan karakteristik dalam segmen tersebut dengan memanfaatkan peluang yang ada untuk menutupi faktor-faktor yang menjadi ancaman, serta melakukan pilihan pasa satu atau semua segmen dengan pertimbangan mampu meningkatkan kinerja dari masing-masing segmen.
\end{abstract}

Kata Kunci: Segmentasi Geografis, Demografis, Psikografis, Perilaku

\section{PENDAHULUAN}

Dalam era modern seperti saat ini, perkembangan dalam dunia bisnis sangat berperan penting bagi perekonomian Indonesia salah satunya adalah bisnis pengolahan bahan pangan siap saji. Bisnis pengolahan bahan pangan siap saji seperti rumah makan, restoran, cafe merupakan salah satu bisnis yang menjanjikan saat ini. Karena rumah makan, restoran dan cafe menyediakan kebutuhan pokok yang dikonsumsi oleh masyarakat.

Perkembangan ini sangat luar biasa dengan melihat begitu banyaknya jumlah rumah makan, restoran dan cafe saat ini, mulai dari 
rumah makan berskala kecil sampai berskala internasional, serta dilihat dari industri rumah makan yang terdiri dari empat segmen pasar yang berbeda, yaitu rumah makan tradisional, restoran, catering dan cafe. Dengan adanya segmentasi pasar ini, menunjukkan jenis konsumen mana yang menjadi target pemasaran rumah makan, restoran dan cafe tersebut.

Hal yang perlu dipahami adalah dengan berorientasi pada peningkatan penjualan dengan menarik konsumen baru, rumah makan memang dapat memperoleh omset yang meningkat dalam sesaat. Namun konsumen baru tersebut tidak bisa menjanjikan akan terus mempertahankan seleranya untuk tetap berkunjung kembali pada rumah makan. Sehingga hal yang lebih baik dilakukan oleh pelaku bisnis rumah makan adalah mempertahankan pelanggan yang telah ada karena mampu memberikan keuntungan jangka panjang yang lebih besar bagi rumah makan tersebut. Hal ini dapat dilakukan dengan cara membuat para pelanggan puas terhadap makanan yang disajikan dalam rumah makan. Semakin tinggi tingkat kepuasan terhadap makanan yang disajikan, semakin tinggi pula tingkat konsumen yang berkunjung dalam rumah makan tersebut.

Salah satu strategi agar rumah makan mampu bersaing adalah dengan memberikan layanan yang terbaik serta membangun citra yang baik di mata konsumen, karena layanan dan citra dapat mempengaruhi proses pembelian suatu produk atau jasa. Oleh karena itu, layanan dan citra menjadi faktor penting bagi keberhasilan pemasaran suatu organisasi (Hurriyati, 2008:21).

Dalam pemasaran, sebelum melakukan berbagai macam strategi, pasar atau segmen yang dipilih harus jelas terlebih dahulu. Karena jika kita melihat saat ini begitu banyak kegagalan bisnis rumah makan yang terjadi, hal ini diakibatkan gagalnya para pelaku bisnis mendefinisikan pasar yang dituju. Mereka bertindak jika mendengar potensi pasar, tetapi tidak bertanya dan meninjau lebih jauh siapa pasar yang ingin dituju dan bagaimanakah potensinya. Setiap rumah makan perlu mengidentifikasikan segmen pasar yang dapat dilayani paling efektif yaitu dengan cara melakukan penelitian segmentasi.

Segmentasi dapat digunakan untuk mengidentifikasi dan membagi segmen berdasarkan karakteristik konsumen. Mengidentifikasi segmen pasar bermanfaat sebagai alat komunikasi yang baik untuk mendeskripsikan setiap segmen tentang manfaat produk yang diinginkan konsumen.

Assauri (2007) membagi segmentasi menjadi empat variabel segmentasi utama bagi konsumen. Variabel segmentasi yang umum digunakan adalah variabel geografis, demografis, psikografis, dan perilaku yang di pandang sangat penting dalam mengukur segmentasi pasar pada pasar modern.

Keberadaan bahan pangan siap saji khususnya rumah makan memang semakin banyak digunakan sebagai tempat kuliner. Di kota Pekanbaru itu sendiri begitu banyak pengolahan bahan siap saji khususnya rumah makan yang sudah didirikan yang banyak dipadati 
pengunjung selaku konsumen, baik itu yang berada di dalam kota itu sendiri maupun yang berada di luar kota. Hal ini dilakukan karena rumah makan banyak menyajikan masakan yang sesuai dengan selera konsumen, mulai dari menyajikan masakan khas padang, melayu, jawa dan lain sebagainya.

Pondok Patin HM. Yunus adalah salah satu rumah makan yang menyajikan masakan khas melayu yang ada di Pekanbaru Riau. Dari tahun ke tahun selalu ramai dengan pengunjung bahkan mampu bertahan dari persaingan pengolahan bahan siap saji lainnya seperti kafe, restoran, pecel lele dan tempat makanan lainnya yang menyajikan kuliner khas dari tempat tersebut.

Pondok Patin HM. Yunus merupakan rumah makan yang dikelola dengan manajemen modern sebagai penyedia makanan tradisional dengan mutu dan pelayanan yang baik kepada konsumen. Jika dilihat masakan yang disajikan di Pondok Patin HM. Yunus, memiliki variasi jenis masakan yang beragam dengan harga yang masih bisa dijangkau oleh masyarakat kelas menengah. Secara kuantitas, Pondok Patin HM. Yunus umumnya memberikan pelayanan cukup baik, misalnya dengan adanya tempat parkir yang luas dan bagian dalamnya juga luas sehingga mampu menampung banyak tamu, produk yang ditawarkan pun tidak terlalu mahal.

Suatu produk yang dapat memenuhi kebutuhan dan keinginan dari konsumen tentunya akan terjual dipasaran dengan syarat target pasar produk tersebut tentunya harus memiliki daya beli. Hal ini juga harus mendapat perhatian dari rumah makan Pondok Patin HM. Yunus agar produk yang ditawarkan kepada konsumen bisa menghasilkan keuntungan yang maksimal. Sebelum memasarkan produk, ada baiknya pelaku bisnis memperhatikan segmen pasar dalam memasarkan produknya yang ada di rumah makan tersebut baik dari segi geografis yaitu memperhatikan konsumennya berasal dari negara, provinsi, kota, desa atau lingkungannya, dari segi demografis yaitu usia, ukuran keluarga, jenis kelamin, pendapatan dan kelas sosial, dari segi psikografis yaitu gaya hidup dan kepribadian konsumen serta dari segi perilaku konsumen itu sendiri. Mengingat konsumen saat ini dihadapkan kepada banyak pilihan dan perubahan perilaku konsumen yang begitu cepat dari waktu ke waktu, sehingga diperlukan penganalisisan program dan strategi yang bagus dalam menjalankan usaha bisnisnya khususnya terhadap Pondok Patin HM. Yunus.

Dengan demikian, sangat dibutuhkan dalam ketepatan mencari strategi mensegmentasi pasarnya untuk memudahkan rumah makan Pondok Patin HM. Yunus dan pemasar dalam membidik pasar sasaran, memposisikan pasar produknya, sehingga akan dapat membuat keputusan yang mampu mempertahankan para pelanggannya sekaligus juga menarik konsumen baru untuk datang berkunjung ke rumah makan tersebut.

Berdasarkan latar belakang masalah di atas, maka penulis meneliti tentang bagaimanakah segmentasi konsumen Pondok Patin 
HM. Yunus Pekanbaru sebagai suatu rumah makan masakan khas melayu.

\section{TINJAUAN PUSTAKA}

Menurut Schiffman dan Kanuk (2008: 37) mendefinisikan segmentasi pasar sebagai proses membagi pasar menjadi irisan-irisan konsumen yang khas yang mempunyai kebutuhan atau sifat yang sama dan kemudian memilih satu atau lebih segmen yang akan dijadikan sasaran bauran pemasaran yang berbeda. Seperti yang dikemukakan oleh Assauri (2007), Ia membagi segmentasi menjadi empat variabel segmentasi utama bagi konsumen.

1. Segmentasi geografis

Segmentasi geografis digunakan untuk mengklasifikasikan pasar berdasarkan lokasi yang akan mempengaruhi biaya operasional dan jumlah permintaan secara berbeda. Dalam segmentasi geografi, pasar dibagi menjadi unit geografis, seperti: negara, provinsi, kota atau lingkungan.

2. Segmentasi demografis

Dalam segmentasi demografis, pasar dibagi menjadi kelompokkelompok berdasarkan variabelvariabel demografis seperti usia, ukuran keluarga, siklus kehidupan keluarga, jenis kelamin, penghasilan, pekerjaan, agama, ras, generasi kewarganegaraan, dan kelas sosial.

3. Segmentasi psikografis

Segmentasi psikografis, segmen pasar ini dilakukan dengan mengelompokkan konsumen atau pembeli menjadi bagian pasar menurut variabel-variabel pola atau gaya hidup (life style) dan kepribadian (personality).
4. Segmentasi perilaku

Dalam segmentasi perilaku pasar diklasifikasi dalam kelompokkelompok yang dibedakan berdasarkan pengetahuan, sikap, penggunaan atau respon terhadap suatu produk.

\section{METODE PENELITIAN \\ Populasi dan Sampel}

Populasi dalam penelitian ini adalah konsumen yang sedang makan ataupun yang pernah makan di Pondok patin HM. Yunus Pekanbaru yaitu sebanyak 63.875 orang konsumen pada tahun 2014. Adapun sampel yang diambil dalam penelitian ini adalah sebanyak 100 orang dengan menggunakan metode accidential sampling , sampel didapat dengan menggunakan rumus slovin yang dikutip dari Andespa (2012:134). Sedangkan teknik pengambilan sampel dilakukan secara convenience sampling, yaitu teknik penentuan sampel berdasarkan kebetulan saja, anggota populasi yang ditemui peneliti dan bersedia menjadi responden dijadikan sampel (Andespa, 2012:140).

\section{Metode Pengumpulan Data}

Penelitian ini merupakan penelitian survey. Sesuai dengan karakteristik penelitian survai, data yang diperoleh merupakan data primer melalui komunikasi (tertulis) dengan responden sebagai sampel individual yang representatif. Cara pengumpulan data dalam penelitian ini dengan menggunakan kuesioner yang berisikan sejumlah pertanyaan.

Tahapan Analysis dan Profiling

1. Analisis Faktor

Analisis factor untuk menyederhanakan hubungan yang komplek dan bermacam-macam 
yang ada diantara sejumlah variabel observasi dengan membuka dimensi atau faktor bersama (common faktor).

2. Analisis Klaster

Analisis kluster merupakan suatu himpunan teknik untuk mengelompokkan objek atau orang yang serupa. Ada dua macam pendekatan dalam melakukan analisis kluster, yaitu hirarkis dan non hirarkis. Metode hirarkis mulai dengan semua variabel dalam satu kluster kemudian dipecah-pecah sampai menjadi single-object cluster. Pendekatan non hirarkis berbeda dalam hal kemampuannya untuk menggabungkan suatu obyek dengan obyek lain saat kluster dibentuk jika hal itu dapat meningkatkan kriteria clustering.

3. Tahapan Pembentukan (Profilling)
Tahap pembentukan (Profilling) meliputi pendeskripsian karakteristik-karakteristik masingmasing yang digunakan untuk membedakan karakteristik tersebut pada dimensi yang relevan. Segmentasi pasar konsumen dapat didasarkan atas dua kelompok besar variabel yaitu karakteristik konsumen dan tanggapan konsumen terhadap produk.

\section{HASIL DAN PEMBAHASAN \\ Karakteristik Konsumen Pondok Patin HM. Yunus}

Di dalam melakukan penelitian segmentasi pasar maka karakteristik konsumen perlu diidentifikasi karena banyaknya konsumen dengan berbagai karakteristik yang berbeda. 
1. Karakteristik Konsumen Berdasarkan Variabel Demografis

Tabel 1

Karakteristik Konsumen Berdasarkan Variabel Demografis

\begin{tabular}{|c|c|c|c|}
\hline \multicolumn{2}{|c|}{ Keterangan } & $\begin{array}{l}\text { Jumlah } \\
\text { (orang) }\end{array}$ & $\begin{array}{c}\text { Persentase } \\
(\%)\end{array}$ \\
\hline Jenis Kelamin & $\begin{array}{l}\text { Pria } \\
\text { Wanita } \\
\quad \text { Total }\end{array}$ & $\begin{array}{c}63 \\
37 \\
100 \\
\end{array}$ & $\begin{array}{c}63,0 \\
37,0 \\
100,0 \\
\end{array}$ \\
\hline Usia & $\begin{array}{l}\text { Di bawah } 20 \text { tahun } \\
21-25 \text { tahun } \\
26-30 \text { tahun } \\
31-35 \text { tahun } \\
\text { Diatas } 35 \text { tahun } \\
\quad \text { Total }\end{array}$ & $\begin{array}{c}5 \\
17 \\
19 \\
23 \\
36 \\
100\end{array}$ & $\begin{array}{c}5,0 \\
17,0 \\
19,0 \\
23,0 \\
36,0 \\
100,0\end{array}$ \\
\hline Status Perkawinan & $\begin{array}{l}\text { Kawin } \\
\text { Tidak kawin } \\
\quad \text { Total }\end{array}$ & $\begin{array}{c}65 \\
35 \\
100 \\
\end{array}$ & $\begin{array}{c}65,0 \\
35,0 \\
100,0\end{array}$ \\
\hline Profesi & \begin{tabular}{l} 
Mahasiswa/Pelajar \\
Karyawan Swasta \\
PNS \\
Tidak Bekerja \\
\multicolumn{1}{c}{ Total }
\end{tabular} & $\begin{array}{c}18 \\
41 \\
33 \\
8 \\
100\end{array}$ & $\begin{array}{c}18,0 \\
41,0 \\
33,0 \\
8,0 \\
100,0\end{array}$ \\
\hline Pendidikan Terakhir & $\begin{array}{l}\text { SMP } \\
\text { SMA } \\
\text { Diploma/Akademi } \\
\text { Sarjana } \\
\text { Lain-lain } \\
\quad \text { Total }\end{array}$ & $\begin{array}{c}2 \\
4 \\
18 \\
46 \\
30 \\
100\end{array}$ & $\begin{array}{c}2,0 \\
4,0 \\
18,0 \\
46,0 \\
30,0 \\
100,0\end{array}$ \\
\hline Pengeluaran/bulan & $\begin{array}{c}\text { Rp. } 500.000-750.000 \\
\text { Rp.750.001- } 1.000 .000 \\
\text { Rp. } 1.000 .001-1.500 .000 \\
\text { Di atas Rp. } 1.500 .000 \\
\text { Total }\end{array}$ & $\begin{array}{c}1 \\
3 \\
7 \\
89 \\
100\end{array}$ & $\begin{array}{c}1,0 \\
3,0 \\
7,0 \\
89,0 \\
100,0\end{array}$ \\
\hline
\end{tabular}


2. Karakteristik Konsumen Berdasarkan Variabel Perilaku

Tabel 2

Karakteristik Konsumen Berdasarkan Variabel Perilaku

\begin{tabular}{|c|c|c|c|}
\hline \multicolumn{2}{|c|}{ Keterangan } & $\begin{array}{l}\text { Jumlah } \\
\text { (orang) }\end{array}$ & $\begin{array}{c}\text { Persentase } \\
(\%)\end{array}$ \\
\hline \multirow[t]{6}{*}{ Intensitas Makan } & $1-2$ kali & 37 & 37,0 \\
\hline & $3-4$ kali & 41 & 41,0 \\
\hline & $5-6$ kali & 11 & 11,0 \\
\hline & $7-8$ kali & 8 & 8,0 \\
\hline & Lebih dari 9 kali & 3 & 3,0 \\
\hline & Total & 100 & 100,0 \\
\hline \multirow[t]{6}{*}{ Jenis Makanan } & Asam Pedas & 42 & 42,0 \\
\hline & Gulai Telur Ikan & 14 & 14,0 \\
\hline & Pepes Ikan Patin & 24 & 24,0 \\
\hline & Selais Goreng & 19 & 19,0 \\
\hline & Lain-lain & 1 & 1,0 \\
\hline & Total & 100 & 100,0 \\
\hline
\end{tabular}

\section{Analisis Faktor}

Analisis faktor didalam penelitian ini bertujuan untuk menyederhanakan suatu variabel dengan cara mengurangi jumlah indikatornyaa. Jadi yang akan disederhanakan adalah variabel gaya hidup yang terdiri dari 22 pernyataan yang berhubungan dengan aktivitas, minat, dan opini menjadi beberapa faktor.

\section{Analisis Faktor Variabel Gaya Hidup}

Proses analisis faktor variabel gaya hidup konsumen yang makan di Pondok Patin HM. Yunus adalah sebagai berikut:

1. Penyusunan matriks data mentah Matriks data mentah untuk variabel gaya hidup berukuran $\mathrm{m}$ $\mathrm{x} n$, dimana $\mathrm{m}$ adalah jumlah responden dan $\mathrm{n}$ adalah jumlah variabel yang dianalisis. Maka disini data mentah berukuran 100 x 22 .

2. Penyusunan matriks korelasi dan matriks Anti-Image
Pada penelitian ini analisis faktor didasari oleh asumsi multikolinearitas. Berdasarkan uji korelasi parsial dalam matriks korelasi diketahui 100 korelasi dari 231 total korelasi adalah 43.3\% pada taraf signifikansi 0.01. Analisis faktor akan dilanjutkan bila jumlah korelasi antar variabel yang signifikan lebih dari $30 \%$, sehingga pada penelitian ini analisisnya dapat dilanjutkan.

3. Komunalitas

Komunalitas suatu variabel menunjukkan ukuran variansi variabel yang dijelaskan oleh faktor-faktor. Kisaran nilai komunalitas antara 0.00 sampai 1.00. Dan dari hasil yang diperoleh menunjukkan semua variabel memiliki komunalitas cukup tinggi, sehingga variabelvariabel tersebut mempunyai persamaan dengan variabel dalam satu kelompok. 
4. Ekstraksi Faktor

Penentuan jumlah faktor dilakukan dengan metode Principal Component dan kriteria yang digunakan adalah kriteria latent roots (eigenvalue) lebih dari 1 maka faktor tersebut signifikan. Dengan kriteria ini, ekstraksi faktor menghasilkan 6 faktor yang dapat digunakan. Dari tabel 3 diketahui total variansi yang dimiliki oleh 6 faktor tersebut adalah 54.983\%. Dengan demikian keenam faktor tersebut mampu menjelaskan $54.983 \%$ variansi secara keseluruhan variabel.

Tabel 3

Total Varian Penjelas

\begin{tabular}{|c|c|c|c|c|c|c|}
\hline \multirow{2}{*}{ Component } & \multicolumn{3}{|c|}{ Initial Eigenvalues } & \multicolumn{3}{|c|}{$\begin{array}{c}\text { Extraction Sums of Squared } \\
\text { Loadings } \\
\end{array}$} \\
\hline & Total & $\begin{array}{c}\% \text { of } \\
\text { Variance }\end{array}$ & $\begin{array}{c}\text { Cumulativ } \\
\text { e \% }\end{array}$ & Total & $\begin{array}{c}\% \text { of } \\
\text { Variance }\end{array}$ & $\underset{\%}{\text { Cumulative }}$ \\
\hline 1 & 3,380 & 15,361 & 15,361 & 3,380 & 15,361 & 15,361 \\
\hline 2 & 2,866 & 13,025 & 28,387 & 2,866 & 13,025 & 28,387 \\
\hline 3 & 1,900 & 8,635 & 37,021 & 1,900 & 8,635 & 37,021 \\
\hline 4 & 1,531 & 6,959 & 43,981 & 1,531 & 6,959 & 43,981 \\
\hline 5 & 1,269 & 5,769 & 49,750 & 1,269 & 5,769 & 49,750 \\
\hline 6 & 1,151 & 5,234 & 54,983 & 1,151 & 5,234 & 54,983 \\
\hline 7 & 1,108 & 5,037 & 60,021 & & & \\
\hline 8 & 1,022 & 4,646 & 64,667 & & & \\
\hline 9 & ,909 & 4,132 & 68,799 & & & \\
\hline 10 &, 865 & 3,934 & 72,733 & & & \\
\hline 11 & ,836 & 3,801 & 76,535 & & & \\
\hline 12 & ,755 & 3,431 & 79,966 & & & \\
\hline 13 & ,687 & 3,124 & 83,090 & & & \\
\hline 14 &, 624 & 2,836 & 85,927 & & & \\
\hline 15 & ,558 & 2,538 & 88,465 & & & \\
\hline 16 & , 488 & 2,217 & 90,682 & & & \\
\hline 17 & ,458 & 2,082 & 92,764 & & & \\
\hline 18 & ,416 & 1,891 & 94,654 & & & \\
\hline 19 & ,380 & 1,728 & 96,382 & & & \\
\hline 20 & ,294 & 1,336 & 97,718 & & & \\
\hline 21 & ,280 & 1,274 & 98,992 & & & \\
\hline 22 & ,222 & 1,008 & 100,000 & & & \\
\hline
\end{tabular}

Sumber : Data olahan primer

Dengan demikian variabelvariabel gaya hidup konsumen Pondok Patin HM. Yunus telah dikelompokkan menjadi 6 faktor. Pemberian nama masing-masing faktor berdasarkan kecenderungan pernyataan gaya hidup yang ada.

Penulis memberikan nama untuk keenam faktor tersebut adalah sebagai berikut: 
Faktor $1 \quad$ : Aktif berorganisasi

Faktor 2 : Optimis

Faktor 3 : Senang kehidupan

modern

Faktor $4 \quad$ : Pemerhati masalah sosial dan politik

Faktor 5 : mengedepankan

status sosial

Faktor 6 : Memperhatikan penampilan

Analisis Klaster

Analisis Klaster Variabel Gaya

Hidup

Tahapan analisis klaster variabel gaya hidup adalah sebagai berikut:

1. Pembentukan profil klaster

Tahap ini meliputi pendeskripsian

karakteristik masing-masing klaster yang digunakan untuk membedakan karakteristik tersebut. Data yang digunakan adalah data yang tidak termasuk dalam prosedur pengklasteran awal, yaitu data variabel gaya hidup melainkan berupa data karakteristik konsumen. Data karakteristik konsumen meliputi demografi dan perilaku, yaitu jenis kelamin, usia, profesi, pendidikan, pengeluaran, rata-rata mengunjungi rumah makan Pondok Patin HM. Yunus dan jenis makanan yang disukai. Profil hasil kluster gaya hidup dapat dilihat pada tabel 4 berikut ini: 
Tabel 4

Profil Klaster Gaya Hidup Berdasarkan Karakteristik Konsumen

\begin{tabular}{|c|c|c|c|c|}
\hline \multicolumn{2}{|r|}{ Variabel } & \multicolumn{2}{|c|}{ Anggota Klaster Gaya Hidup } & \multirow{2}{*}{ Total } \\
\hline & & 1 & 2 & \\
\hline \multirow[t]{3}{*}{ Jenis Kelamin } & Pria & $39(61.9 \%)$ & $24(38.1 \%)$ & $63(100.0 \%)$ \\
\hline & Wanita & $22(59.5 \%)$ & $15(40.5 \%)$ & $37(100.0 \%)$ \\
\hline & Total & $61(61.0)$ & $39(39.0 \%)$ & $100(100.0 \%)$ \\
\hline \multirow[t]{6}{*}{ Umur } & Dibawah 20 tahun & $0(0 \%)$ & $5(100.0 \%)$ & $5(100.0 \%)$ \\
\hline & $21-25$ tahun & $0(0 \%)$ & $17(100.0 \%)$ & $17(100.0 \%)$ \\
\hline & $26-30$ tahun & $2(10.5 \%)$ & $17(89.5 \%)$ & $19(100.0 \%)$ \\
\hline & $31-35$ tahun & $23(100.0 \%)$ & $0(0 \%)$ & $23(100.0 \%)$ \\
\hline & Di atas 35 tahun & $36(100.0 \%)$ & $0(0 \%)$ & $36(100.0 \%)$ \\
\hline & Total & $61(61.0 \%)$ & $39(39.0 \%)$ & $100(100.0 \%)$ \\
\hline \multirow[t]{5}{*}{ Profesi } & Mahasiswa/pelajar & $8(44.4 \%)$ & $10(55.6 \%)$ & $18(100.0 \%)$ \\
\hline & Karyawan Swasta & $24(58.5 \%)$ & $17(41.5 \%)$ & $41(100.0 \%)$ \\
\hline & PNS & $22(66.7 \%)$ & $11(33.3 \%)$ & $33(100.0 \%)$ \\
\hline & Tidak bekerja & $7(87.5 \%)$ & $1(12.5 \%)$ & $8(100.0 \%)$ \\
\hline & Total & $61(61.0 \%)$ & $39(39.0 \%)$ & $100(100.0 \%)$ \\
\hline \multirow{6}{*}{\multicolumn{2}{|c|}{ Pendidikan terakhir }} & $1(50.0 \%)$ & $1(50.0 \%)$ & $2(100.0 \%)$ \\
\hline & & $4(100.0 \%)$ & $0(0 \%)$ & $4(100.0 \%)$ \\
\hline & & $14(77.8 \%)$ & $4(22.2 \%)$ & $18(100.0 \%)$ \\
\hline & & $27(58.7 \%)$ & $19(41.3 \%)$ & $46(100.0 \%)$ \\
\hline & & $15(50.0 \%)$ & $15(50.0 \%)$ & $30(100.0 \%)$ \\
\hline & & $61(61.0 \%)$ & $39(39.0 \%)$ & $100(100.0 \%)$ \\
\hline \multirow{5}{*}{$\begin{array}{rr}\text { Pengeluaran } & \mathrm{F} \\
\mathrm{R} & \mathrm{R} \\
\mathrm{D}\end{array}$} & $.500 .00-$ Rp.750.000 & $1(100.0 \%)$ & $0(0 \%)$ & $1(100.0 \%)$ \\
\hline & $750.00-\mathrm{Rp} 1.000 .000$ & $1(33.3 \%)$ & $2(66.7 \%)$ & $3(100.0 \%)$ \\
\hline & 1.000.001-Rp.1.500.000 & $4(57.1 \%)$ & $3(42.9 \%)$ & $7(100.0 \%)$ \\
\hline & tas Rp.1.500.000 & $55(61.8 \%)$ & $34(38.2 \%)$ & $89(100.0 \%)$ \\
\hline & Total & $61(61.0 \%)$ & $39(39.0 \%)$ & $100(100.0 \%)$ \\
\hline Rata-rata & $1-2$ kali & $21 \quad(56.8 \%)$ & $16(43.2 \%)$ & $37(100.0 \%)$ \\
\hline \multirow[t]{5}{*}{ Mengunjungi } & 3-4 kali & $26(63.4 \%)$ & $15(36.6 \%)$ & $41(100.0 \%)$ \\
\hline & 5-6 kali & $5(45.5 \%)$ & $6(54.5 \%)$ & $11(100.0 \%)$ \\
\hline & $7-8$ kali & $6(75.0 \%)$ & $2(25.0 \%)$ & $8(100.0 \%)$ \\
\hline & Lebih dari 9 kali & $2(100.0 \%)$ & $0(0 \%)$ & $2(100.0 \%)$ \\
\hline & Total & $61(61.0 \%)$ & $39(39.0 \%)$ & $100(100.0)$ \\
\hline \multirow{6}{*}{$\begin{array}{l}\text { Jenis makanan } \\
\text { yang disukai }\end{array}$} & Asam pedas patin & $23(54.8 \%)$ & $19(45.2 \%)$ & $42(100.0 \%)$ \\
\hline & Gulai telur ikan & $11(78.6 \%)$ & $3(21.4 \%)$ & $14(100.0 \%)$ \\
\hline & Pepes ikan patin & $14(58.3 \%)$ & $10(41.7 \%)$ & $24(100.0 \%)$ \\
\hline & Selais goreng & $13(68.4 \%)$ & $6(31.6 \%)$ & $19(100.0 \%)$ \\
\hline & Lain-lain & $0(0 \%)$ & $1(100.0 \%)$ & $1(100.0 \%)$ \\
\hline & Total & $61(61.0 \%)$ & $39(39.0 \%)$ & $100(100.0 \%)$ \\
\hline
\end{tabular}

Sumber : Data olahan primer 
2. Uji Chi-square klaster gaya hidup berdasarkan karakteristik responden

Uji Chi-square yang dilakukan pada klaster gaya hidup berdasarkan karakteristik responden ini bertujuan untuk mengetahui signifikansi perbedaan proporsi responden ditinjau dari karakteristiknya. Hasil pengujian disajikan dalam tabel 5 berikut ini:

Tabel 5

Uji Chi-Square Klaster Gaya Hidup Berdasarkan Karakteristik Konsumen

\begin{tabular}{|l|c|c|c|}
\hline \multicolumn{1}{|c|}{ Variabel } & Nilai Chi-square & df & Signifikansi \\
\hline Jenis kelamin & 0.059 & 1 & 0.809 \\
Usia & 92.478 & 4 & 0.000 \\
Profesi & 4.985 & 3 & 0.173 \\
Pendidikan terakhir & 6.417 & 4 & 0.170 \\
Pengeluaran & 1.672 & 3 & 0.643 \\
Rata-rata mengunjungi & 4.075 & 4 & 0.396 \\
Jenis makanan yang disukai & 4.580 & 4 & 0.333 \\
& & & \\
& & & \\
\hline
\end{tabular}

Sumber: Data olahan primer

Hasil uji Chi-square menunjukkan bahwa variabel umur berbeda secara signifikan dalam segmen 1 (Segmen Aktif) dan segmen 2 (Segmen Pasif), dengan taraf signifikansi $0.000(\mathrm{p}<$ 0.005). Sementara variabel karakteristik konsumen lainnya tidak menunjukkan perbedaan yang signifikan antara kedua segmen.

\section{PENUTUP}

\section{Kesimpulan}

1. Karakteristik Konsumen Pondok Patin HM. Yunus
a. Berdasarkan
Variabel Demografi

Konsumen Pondok Patin HM. Yunus yang berjenis kelamin pria berjumlah 63 orang $(63 \%)$ dan wanita berjumlah 37 orang (37\%), sehingga dapat disimpulkan bahwa sebagian besar konsumen Pondok Patin HM.
Yunus adalah pria. Ditinjau dari segi usia, konsumen rumah makan Pondok Patin HM. Yunus sebagian besar berusia diatas 25 tahun yaitu berusia antara 26-30 tahun berjumlah 19 orang (19\%), berusia 31-35 tahun berjumlah 23 orang (23\%), dan yang berusia diatas 35 tahun berjumlah 36 orang (36\%). Maka dapat disimpulkan bahwa konsumen rumah makan Pondok Patin HM. Yunus berada pada usia dewasa. Profesi konsumen Pondok Patin HM. Yunus sebagian besar adalah karyawan swasta berjumlah 41 orang $(41 \%)$, PNS berjumlah 33 orang (33\%), mahasiswa/pelajar berjumlah 18 orang (18\%) dan yang tidak bekerja berjumlah 8 orang 
(8\%). Jadi dapat disimpulkan bahwa konsumen Pondok Patin HM. Yunus di Pekanbaru sebagian besar karyawan sasta dan PNS.

Tingkat pendidikan konsumen yang berkunjung di Pondok Patin HM. Yunus sebagian besar adalah diploma/akademik berjumlah 18 orang (18\%), sarjana 46 orang (46\%) dan lainnya seperti Pascasarjana, Doktor dan Professor berjumlah 30 orang (30\%). Maka dapat dikatakan bahwa konsumen rumah makan Pondok Patin banyak dikunjungi oleh orang yang memiliki latar belakang pendidikan sarjana maupun diploma.

Sedangkan pengeluaran mereka adalah dari Rp. $500.000 \quad-\quad$ Rp. 750.000 berjumlah 1 orang (1\%), antara Rp. 750.001 - Rp. 1.000 .000 berjumlah 3 orang (3\%), antara Rp. 1.000.001 - Rp. 1.500.000 berjumlah 7 orang $(7 \%)$ dan diatas Rp. 1.500 .000 berjumlah 89 orang (89\%). Sehingga dapat disimpulkan bahwa konsumen Pondok Patin HM. Yunus adalah mereka yang berada dikalangan menengah keatas yang berarti konsumen Pondok Patin HM. Yunus mempunyai kemampuan untuk menjangkau harga makanan di rumah makan Pondok Patin HM. Yunus.

b. Berdasarkan Variabel Perilaku

Berdasarkan dari ratarata mengunjungi rumah makan Pondok Patin HM. Yunus, konsumen yang mengunjungi $\quad 1-2 \quad$ kali berjumlah 37 orang (37\%), 3-4 kali berjumlah 41 orang (41\%), 5-6 kali berjumlah 11 orang (11\%), 7-8 kali berjumlah 8 orang $(8 \%)$ dan lebih dari 9 kali berjumlah 3 orang (3\%). Sehingga dapat disimpulkan bahwa intensitas konsumen untuk mengunjungi rumah makan Pondok Patin HM. Yunus terbilang sangat rendah. Untuk jenis makanan yang disukai, konsumen yang menyukai asam pedas patin berjumlah 42 orang (42\%), gulai telur ikan berjumlah 14 orang (14\%), pepes ikan patin berjumlah 24 orang (24\%), selais goreng berjumlah 19 orang $(19 \%)$ dan yang lainnya berjumlah 1 orang (1\%). Jadi dapat disimpulkan bahwa sebagian besar konsumen jika berkunjung ke Pondok Patin HM. Yunus menyukai asam pedas patin yang ditawarkan oleh rumah makan tersebut yang merupakan ciri khas masakan melayu.

2. Analisis Faktor

Dari hasil analisis faktor dihasilkan 6 faktor berdasarkan variabel gaya hidup konsumen rumah makan Pondok Patin HM. Yunus. Keenam variabel gaya hidup ini adalah:

a. Faktor 1 : aktif berorganisasi

b. Faktor 2 : optimis

c. Faktor 3 : senang kehidupan modern

d. Faktor 4 : pemerhati masalah sosial dan politik

e. Faktor 5: mengedepankan status social 
f. Faktor 6 : memperhatikan penampilan

3. Analisis Kluster

a. Segmen Aktif

Pada segmen ini, karakteristik yang mendasari dan membedakannya secara signifikandengan segmen pasif adalah jenis kelamin, usia, profesi, pendidikan, rata-rata pengunjung dan jenis makanan yang disukai pada rumah makan Pondok Patin HM. Yunus lebih besar dibanding segmen pasif yaitu sebesar $61 \%$. Dengan kata lain segmen aktif menganggap lebih penting variabel gaya hidup dibandingkan dengan segmen pasif.

b. Segmen Pasif

Pada segmen ini, variabel gaya hidup tidak dianggap begitu penting dibandingkan dengan segmen aktif hal ini bisa dilihat dari kecenderungan yang merata terhadap semua segmen seperti jenis kelamin, usia, profesi, pendidikan, rata-rata pengunjung dan jenis makanan yang disukai pada rumah makan Pondok Patin HM. Yunus lebih kecil dibanding segmen aktif yaitu sebesar $39 \%$.

Dari uji Chi-square yang dilakukan terhadap klaster gaya hidup berdasarkan karakteristik responden menunjukkan, terdapat perbedaan proporsi karakteristik yang signifikan antara segmen aktif dan segmen pasif berdasarkan karakteristik konsumen yaitu pada usia dengan tingkat signifikansi $0.000 \quad(\mathrm{p}<0.005)$. Sementara variabel lainnya tidak berbeda secara signifikan.

\section{Saran}

1. Dengan adanya segmen-segmen yang telah diketahui yaitu segmen aktif dan segmen pasif, rumah makan Pondok Patin HM. Yunus Pekanbaru dapat melakukan pemilihan terhadap salah satu atau beberapa segmen yang pangsa pasarnya besar dan jumlah pesaingnya sedikit dan menguntungkan. Dengan hanya berkonsentrasi pada salah satu atau beberapa segmen maka perusahaan dapat melakukan kegiatan promosi yang sesuai dengan target pasar yang akan dituju.

2. Untuk mempertahankan posisinya di persaingan pasar, rumah makan Pondok Patin HM. Yunus hendaknya dapat mempelajari pergeseran-pergeseran yang terjadi di dalam segmennya. Untuk itu rumah makan Pondok Patin HM. Yunus dapat selalu melakukan kembali prosedur segmentasi pasar sehingga perusahaan dapat selalu memperhatikan terhadap segmensegmen baru yang terbentuk.

3. Dengan memahami segmensegmen yang telah ada maka rumah makan Pondok Patin HM. Yunus dapat mendesain produk yang sesuai dengan kebutuhankebutuhan segmen-segmen tersebut atau dapat juga melakukan pengembangan produk. 


\section{DAFTAR PUSTAKA}

Assauri, Sofjan. (2007). Manajemen Pemasaran, Penerbit Raja Grafindo Pusada, Jakarta.

Andespa, Roni. (2012). Metodologi Riset Bisnis, Penerbit Al-Huda Press, Pekanbaru.

Hurriyati, Ratih. (2008). Bauran Pemasaran dan Loyalitas Konsumen, Alfabeta, Bandung.

Kasali, Rhenald. (2006). Manajemen Public Relations, Penerbit Gramedia Pustaka, Jakarta.

Kotler, Philip dan Armstrong, Garv. (2008). Prinsip-prinsip Pemasaran, Penerbit Erlangga, Jakarta.

Kotler, Philip dan Keller, Kevin Lane. (2009). Manajemen Pemasaran Jilid 2, Penerbit Erlangga, Jakarta.

Schiffman dan Kanuk. (2008). Perilaku Konsumen, Penerbit Indeks, Jakarta.

Sugiyono. (2008). Metode Penelitian

Bisnis. Penerbit Alfabeta. Bandung 